\title{
Indole-3-Acetic Acid-Producing Bacteria Are Associated with Cranberry Stem Gall
}

\author{
Archana Vasanthakumar and Patricia S. McManus
}

Department of Plant Pathology, University of Wisconsin, Madison 53706.

Accepted for publication 1 July 2004.

\begin{abstract}
Vasanthakumar, A., and McManus, P. S. 2004. Indole-3-acetic acidproducing bacteria are associated with cranberry stem gall. Phytopathology 94:1164-1171.

Cranberry stem gall is characterized by tumors that girdle stems, thereby killing all distal leaves, flowers, and fruit. Among bacteria isolated from galls, all 11 isolates that were identified as members of the family Enterobacteriaceae caused galls on 50 to $100 \%$ of micropropagated cranberry plants that were inoculated. Four of fifteen isolates identified as Pseudomonas spp. caused galls on 10 to $83 \%$ of plants inoculated. Twelve of fifteen isolates identified as either Agrobacterium spp. or Rhizobium spp. caused galls on 10 to $50 \%$ of plants inoculated, but the galls were smaller than those caused by members of the family
\end{abstract}

ABSTRACT

The large American cranberry (Vaccinium macrocarpon Ait.) is a woody evergreen vine indigenous to eastern North America. Most commercial plantings of cranberry are established in excavated beds by disking vine cuttings into sand. With adequate soil moisture, cuttings produce adventitious roots within a few weeks. Within 3 to 4 years, the vines form a dense carpet of prostrate stems from which vertical shoots arise. Shoots elongate by about 5 to $10 \mathrm{~cm}$ per year, and fruit are produced on the current year's growth. In most regions where cranberries are produced, the crop is harvested by flooding beds in early fall and then dislodging fruit with mechanical reels or rakes. In Wisconsin, beds are flooded again during early winter to form an ice layer to prevent low-temperature injury and desiccation of plants. The flood is withdrawn in early spring, after which frost protection is accomplished either by sprinkler irrigation or reflooding.

A disorder of cranberry referred to as stem canker was reported in Massachusetts in $1992(9,10)$. Symptoms reported were stem swelling, shoot dieback, and vascular discoloration. Bacterial streaming was observed and two morphologically distinct types of bacteria were isolated from galls. However, inoculation of bacteria onto woody plant stems did not result in stem canker symptoms. In Wisconsin, where symptoms were severe and widespread in 1998 and 2002, the disorder has been referred to as stem canker or "beater damage," under the assumption that stem swelling was caused by wound callus tissue that developed following injury from harvest machinery. We have renamed the malady "stem gall" to more accurately reflect the most characteristic symptoms $(4,31,32)$. Because the cranberry canopy is dense and stems are obscured by foliage, stem gall usually is not detected until after galls have girdled stems and killed distal leaves, flowers, and fruit. Stem tissues proximal to galls remain

Corresponding author: P. S. McManus; E-mail address: psm@ plantpath.wisc.edu

Publication no. P-2004-0913-01R

(c) 2004 The American Phytopathological Society
Enterobacteriaceae or Pseudomonas spp. There was a positive correlation between the ability of bacteria to produce IAA in vitro and cause galls. In 2002 and 2003, bacteria were isolated from plant and soil samples collected from beds where stem gall had been observed in the past 2 years and beds where stem gall had never been observed. IAA-producing bacteria were common in all samples, although trends were different across years. The results of this study support the hypothesis that IAA-producing bacteria cause cranberry stem gall and suggest that rather than one bacterial species being the cause, multiple strains of bacteria that produce IAA may be responsible for gall formation.

Additional keywords: Enterobacter, Erwinia herbicola, Pantoea agglomerans, Vaccinium macrocarpon.

healthy and give rise to new lateral shoots, although affected vines require 2 to 3 years to regain full productivity.

In preliminary investigations, we isolated bacteria $(31,32)$ and fungi from cranberry galls. Fungal genera included Epicoccum, Alternaria, and Pestalotia, all of which are believed to be saprophytic on cranberry (11). These fungi were also isolated from healthy cranberry stems. No fungal reproductive structures or resting spores distinctive of higher fungi, chytridiomycetes, or oomycetes were consistently observed on symptomatic stems. Bacterial populations were typically $10^{3}$ - to $10^{4}$-fold greater per gram of galled tissue than healthy stem tissue (P. S. McManus, unpublished data). Low to moderate populations (4 to 64 nematodes per $100 \mathrm{~cm}^{3}$ of soil) of Hemicycliophora spp. (sheath nematode) were detected in soil of affected cranberry beds (P. S. McManus, unpublished data). However, similar populations of Hemicycliophora spp. were detected in soil surrounding healthy plants and have been recovered in most cranberry-growing regions of North America with no apparent association with stem gall $(2,5,11)$.

Galls on plants develop as a result of an imbalance of growth hormones, usually indole-3-acetic acid (IAA) and cytokinins (13). The best-studied tumorigenic organism, Agrobacterium tumefaciens, which causes crown gall disease on many plants, transfers its genes for hormone biosynthesis to the host, which then produces hormones in excess (14). Pseudomonas savastanoi, which causes knot disease on olive and oleander, and Erwinia herbicola pv. gypsophilae, which causes galls on Gypsophila paniculata, secrete IAA into host tissues $(12,30)$. Russet on apple skin is characterized by abnormal proliferation of epidermal cells (3), presumably the result of IAA produced by E. herbicola and Pseudomonas spp. (22). Plant growth hormones produced by bacteria also can contribute to bacterial fitness $(7,25)$ and mediate beneficial relationships with plants (28).

Recognizing the ubiquity of IAA-producing bacteria in the environment (28), their role in causing galls $(8,12,14,30)$, and the association of bacteria with cranberry stem galls $(4,31,32)$, we hy- 
pothesized that IAA-producing bacteria cause cranberry stem gall. The aims of this study were to (i) identify bacteria that are associated with cranberry stem gall and that are capable of causing symptoms on cranberry plants, (ii) determine whether there is a relationship between the ability of bacteria to produce IAA in vitro and cause galls, and (iii) compare IAA production among bacteria isolated from plants and soil at sites where stem gall has or has not been detected. In an accompanying report (4), we describe the localization of bacteria within galls and anatomical features of cranberry stem gall that are consistent with elevated levels of IAA.

\section{MATERIALS AND METHODS}

Bacterial strains. The bacterial strains used in this study are listed in Tables 1, 2, and 3. Symptomatic stems were collected in central Wisconsin from two sites in 1998, one site in 1999, and eight sites in 2002. Galls were rinsed in tap water and then in sterile distilled water for $30 \mathrm{~min}$. They were then macerated in 0.5 to $1.0 \mathrm{ml}$ of water and allowed to sit for $10 \mathrm{~min}$, after which the macerate was streaked onto media amended with cycloheximide (100 mg/liter). In 1998 and 1999, we suspected that the cranberry pathogen(s) was related to the well-characterized plant gall pathogens, Agrobacterium spp. and/or Pantoea agglomerans (formerly E. herbicola [16]). Therefore, microbes were isolated on potato dextrose agar (Difco Laboratories, Becton Dickinson Microbiology Systems, Sparks, MD), D1 medium (18), and New and Kerr medium (27), which are favorable for Agrobacterium spp.; and Miller-Schroth medium (26), which is selective for Erwinia spp. By 2002, we suspected that $P$. agglomerans was the pathogen (31); therefore we used King's medium B (KB) (19) to differentiate $P$. agglomerans from fluorescent Pseudomonas spp. In addition to streaking macerates, small pieces of galls were placed directly onto media to isolate bacteria. Representative colonies of the predominant morphological types of bacteria isolated from galls were stored in $20 \%$ glycerol at $-80^{\circ} \mathrm{C}$.

Identification of bacteria by $16 \mathrm{~S}$ rRNA gene sequencing. Bacteria were grown for 16 to $24 \mathrm{~h}$ at room temperature with shaking (200 rpm) in Luria-Bertani (LB; Difco Laboratories) broth. An aliquot $(0.5$ to $1 \mathrm{ml})$ of each culture was transferred to a $1.5-\mathrm{ml}$ microcentrifuge tube, pelleted, resuspended in the same volume of water, and heated at $65^{\circ} \mathrm{C}$ for 15 to $30 \mathrm{~min}$ to form a crude lysate that was used as template in polymerase chain reactions (PCRs). Primers used to amplify the conserved 16S rRNA gene (27F [5'-AGAGTTTGATCMTGGCTCAG-3'] and 1492R [5'-TACGGYTACCTTGTTACGACTT-3']) (20) were synthesized at the University of Wisconsin (UW) Biotechnology Center (Madison, WI). PCR was performed in a total volume of $100 \mu \mathrm{l}$.
Each reaction tube contained $10 \mu \mathrm{l}$ of Buffer A (Promega Corp., Madison, WI; $50 \mathrm{mM} \mathrm{KCl}, 10 \mathrm{mM}$ Tris- $\mathrm{HCl}$ [pH 9.0], and $0.1 \%$ Triton X-100); $5 \mu \mathrm{l}$ of template; $1.5 \mathrm{mM} \mathrm{MgCl}{ }_{2} ; 200 \mu \mathrm{M}$ each dATP, dCTP, dGTP, and dTTP; 2 units of Taq DNA polymerase (Promega); and $0.2 \mu \mathrm{M}$ each primer. Samples were overlaid with a drop of mineral oil (Sigma Chemical, St. Louis, MO) and amplified in a thermalcycler (MiniCycler; MJ Research, Watertown, MA). Initial denaturation was at $94^{\circ} \mathrm{C}$ for $3 \mathrm{~min}$ followed by 30 cycles of denaturation at $95^{\circ} \mathrm{C}$ for $1 \mathrm{~min}$, annealing at $55^{\circ} \mathrm{C}$ for $1 \mathrm{~min}$, and extension at $72^{\circ} \mathrm{C}$ for $1.5 \mathrm{~min}$ followed by a final extension at $72^{\circ} \mathrm{C}$ for $5 \mathrm{~min}$ (20). PCR products were purified using a PCR purification kit (QiaQuick; Qiagen Inc., Valencia, CA). Sequencing was performed on an automated sequencer (3730xl DNA Analyzer; Applied Biosystems, Foster City, CA) at the UW Biotechnology Center. Contiguous DNA sequences were assembled using Seqman (DNASTAR, Madison, WI) and compared with sequences recorded in public databases using NCBI BLAST (1).

Pathogenicity tests-woody plants. The pathogenicity of bacteria isolated from cranberry galls was tested on woody cranberry plants (cv. Stevens) using four methods for wounding and inoculating. Bacterial strains used were P. agglomerans 4/99 and A. rubi $1 / 99$, both of which were isolated from cranberry galls. In some experiments, treatments included mixtures of the two strains. Additionally, A. tumefaciens strains C58 and 759, which are known to carry the tumor-inducing plasmid, were included in some tests. In all experiments, control stems were not inoculated but otherwise treated the same as test stems. One method entailed wounding woody stems with either a needle or a scalpel blade, smearing bacteria onto wounds, covering the inoculation site with Parafilm "M" (Pechiney Plastic Packaging, Chicago, IL), and observing stems daily for symptoms. In a second set of experiments, leaves were removed from a portion of woody stems and the leaf abscission zones were inoculated and covered with Parafilm "M". In a third experiment, stem cuttings were rooted in bacterial suspensions $\left(0,10^{4}, 10^{6}\right.$, and $10^{7} \mathrm{CFU}$ per $\mathrm{ml}$ of water) for 8 days, planted in peat plus sand $(3: 1, \mathrm{vol} / \mathrm{vol})$, and then observed for symptoms over a 3-month period. Finally, we attempted to simulate field conditions by placing mats of cranberry vines in tubs $(0.59$ by $0.43 \mathrm{~m})$, dragging a heavy metal tool across vines, flooding with water collected from a cranberry marsh, and adding bacterial inoculum to a final cell density of approximately $10^{6} \mathrm{CFU} / \mathrm{ml}$.

Pathogenicity tests-micropropagated plants. Cranberry plants were grown in the laboratory by inserting the basal ends of succulent shoots (cv. Stevens) into $50 \mathrm{ml}$ of Woody Plant Medium (WPM [23], PhytoTechnology Laboratories, Shawnee Mission, KS) plus vitamins $(5 \mathrm{mg}$ of nicotinic acid, $5 \mathrm{mg}$ of pyridoxine $\mathrm{HCl}$,

TABLE 1. Previously described bacteria used in this study

\begin{tabular}{|c|c|c|c|c|c|}
\hline Strain & Host & Bacterial species & Plants with galls $(\%)^{\mathrm{x}}$ & IAA $(\mu \mathrm{g} / \mathrm{ml})^{\mathrm{y}}$ & Source or reference ${ }^{z}$ \\
\hline 13335 & Raspberry & Agrobacterium rubi & 83 & 0.7 & ATCC \\
\hline $\mathrm{C} 58$ & Cherry & Agrobacterium tumefaciens & 94 & 0.0 & J. Handelsman \\
\hline 759 & Cherry & $\begin{array}{l}\text { Agrobacterium tumefaciens } \\
\text { (C58 derivative) }\end{array}$ & 92 & 0.0 & J. Handelsman \\
\hline BB5 & Apple & Erwinia amylovora & 67 & 0.1 & A. Jones \\
\hline $112 \mathrm{Y}$ & Apple & Erwinia herbicola & 73 & 6.9 & S. Beer \\
\hline 299R & Pear & Erwinia herbicola & 92 & 4.6 & 6 \\
\hline MX149 & 299R ( $\Delta i p d c)$ & Erwinia herbicola & 67 & 4.6 & 6 \\
\hline SS104 & Corn & Pantoea stewartii & 70 & 6.6 & D. Coplin \\
\hline 1288 & Beet & Erwinia herbicola pv. betae & 100 & 9.4 & 8 \\
\hline $824-1$ & Gypsophila & Erwinia herbicola pv. gypsophilae & 100 & 4.9 & 25 \\
\hline 19358 & Unknown & Rhizobium radiobacter & 3 & 0.2 & ATCC \\
\hline
\end{tabular}

$\mathrm{x}$ Percentage of micropropagated plants inoculated on which galls formed.

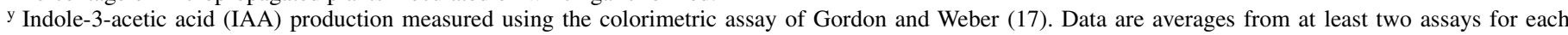
isolate.

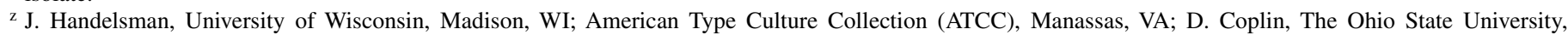
Wooster, OH; S. Beer, Cornell University, Ithaca, NY; and A. Jones, Michigan State University, East Lansing, MI. 
and $50 \mathrm{mg}$ of thiamine $\mathrm{HCl})$ in Magenta boxes $(6 \times 6 \times 10 \mathrm{~cm}$; PhytoTechnology Laboratories). Six to ten plants were wounded at the third internode from the apical meristem with a sterile 27gauge needle and inoculated with bacteria. In different experiments, bacteria were grown for 24 to $48 \mathrm{~h}$ either on solid or in liquid media. Bacterial suspensions were delivered using a pipette or were smeared with a toothpick onto the wounded region of the plant. Control plants were wounded but not inoculated with bacteria. Treated plants were transferred to fresh WPM and incubated at $27^{\circ} \mathrm{C}$ with a 12 -h photoperiod provided by fluorescent lamps. Plants were monitored once per week for symptoms.

Dose-response studies. To determine the number of bacteria required for symptom development, cranberry plants were inoculated with $P$. agglomerans 4/99, E. herbicola 299R (6), and E. herbicola MX149R (E. herbicola 299R $\Delta i p d C$, which produces 10 -fold less IAA than the wild-type parent [6]). Six to ten plants were wounded, inoculated with 1 to $2 \mu \mathrm{l}$ of bacterial suspension containing 0 to $10^{9} \mathrm{CFU}$, and then incubated as described previously. The experiment was performed twice.

Effect of synthetic IAA. Micropropagated plants were wounded as described previously, and $1 \mu \mathrm{l}$ of $50 \%$ ethanol containing $0.0,0.1,0.5,1.0,2.0,5.0$, or $10.0 \mu \mathrm{g}$ of synthetic IAA (Sigma Chemical) was delivered to the wound. Six to ten plants were treated with each concentration of IAA and incubated as described previously. The experiment was performed three times.

Bacterial production of IAA. The colorimetric assay described by Gordon and Weber (17) was used to measure IAA production in vitro by bacteria. In 2002, bacteria were grown in LB broth amended with tryptophan $(200 \mu \mathrm{M})$. In 2003 , bacteria were grown in 50\% tryptic soy broth (Sigma Chemical) amended with tryptophan $(200 \mu \mathrm{M})$. Bacteria were grown with shaking $(200 \mathrm{rpm})$ for $48 \mathrm{~h}$ in the dark at room temperature. Cells were pelleted by centrifugation $(14,000 \mathrm{rpm})$ for $5 \mathrm{~min}$. One milliliter of culture

TABLE 2. Characterization of bacteria isolated from cranberry stem galls

\begin{tabular}{|c|c|c|c|}
\hline Strain & 16S rRNA gene sequence identity ${ }^{w}$ & Plants with galls $(\%)^{\mathrm{x}}$ & IAA $(\mu \mathrm{g} / \mathrm{ml})^{\mathrm{y}}$ \\
\hline \multicolumn{4}{|c|}{ Enterobacteriaceae } \\
\hline SRBL 3.3 & Enterobacter aerogenes $(97)$ & 100 & 9.9 \\
\hline CS 5.1 & Enterobacter cloacae (92) & 83 & 7.3 \\
\hline PS 5.1 & Enterobacter intermedius, Kluyvera cryocrescens (95) & 50 & 3.9 \\
\hline $4 / 99$ & Pantoea agglomerans (96) & 85 & 4.5 \\
\hline $5 / 99$ & Pantoea agglomerans (96) & 80 & 6.5 \\
\hline JRST $3.2 \mathrm{Y}$ & Pantoea agglomerans (98) & 83 & 5.9 \\
\hline PTST3.2 & Serratia fonticola (97) & 67 & 2.6 \\
\hline \multicolumn{4}{|c|}{ Agrobacterium/Rhizobium } \\
\hline S1 & Agrobacterium rubi (99) & 10 & 1.9 \\
\hline $1 / 99$ & Agrobacterium rubi (99) & 28 & 1.9 \\
\hline $3 / 99$ & Agrobacterium rubi (99) & 21 & 1.7 \\
\hline $\mathrm{BL}$ & Agrobacterium rubi (98) & $\mathrm{NT}^{\mathrm{z}}$ & 0.0 \\
\hline DRST2.4 & Agrobacterium rubi, Rhizobium rubi (98) & 33 & 2.9 \\
\hline GBL 3.4 & Agrobacterium rubi, Rhizobium sp. (97) & 33 & 1.2 \\
\hline PS 8.32 & Agrobacterium rubi, Rhizobium sp. (95) & 33 & 1.7 \\
\hline DRST1.4 & Agrobacterium rubi, Rhizobium sp. (97) & 50 & 0.8 \\
\hline GBL 4.1 & Agrobacterium tumefaciens, Rhizobium sp. (95) & 25 & 1.1 \\
\hline GBL 4.4 & Agrobacterium tumefaciens, Rhizobium sp. (98) & 17 & 0.9 \\
\hline PS 5.21 & Rhizobium sp. (98) & 17 & 0.0 \\
\hline \multicolumn{4}{|c|}{ Pseudomonas spp. } \\
\hline GPil 3.2 & Pseudomonas gingeri (95) & 0 & 4.5 \\
\hline JRBL 3.3 & Pseudomonas gingeri (96) & 83 & 4.7 \\
\hline GBL 7.3 & Pseudomonas gingeri $(96)$ & 10 & 3.1 \\
\hline GBL 3.6 & Pseudomonas marginalis (97) & 0 & 1.4 \\
\hline GPil 1.1 & Pseudomonas marginalis (97) & 0 & 1.3 \\
\hline \multicolumn{4}{|c|}{ 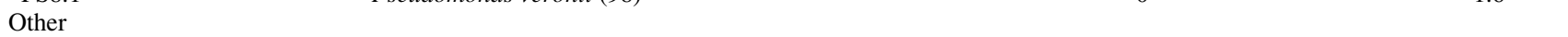 } \\
\hline GTBL1.7 & Chrysobacterium scophthalmum (97) & 0 & 0.0 \\
\hline JRBL 4.3 & Xanthomonas campestris pv. campestris (97) & 17 & 5.2 \\
\hline
\end{tabular}

${ }^{\mathrm{w}}$ Bacteria identified by $16 \mathrm{~S}$ rRNA gene sequencing; numbers in parentheses indicate percent sequence identity to taxa in the database. If two taxa are listed, there was a tie in percent sequence identity.

${ }^{x}$ Percentage of micropropagated plants inoculated on which galls formed.

${ }^{y}$ Indole-3-acetic acid (IAA) production measured using the colorimetric assay of Gordon and Weber (17). Data are averages from at least two assays for each isolate.

${ }^{\mathrm{z}} \mathrm{NT}$, not tested. 
supernatant was added to $2 \mathrm{ml}$ of Salkowsky's reagent $(1 \mathrm{ml}$ of $0.5 \mathrm{M} \mathrm{FeCl}_{3}$ plus $50 \mathrm{ml}$ of $35 \%$ [vol/vol] $\mathrm{HClO}_{4}$ ) and incubated for $30 \mathrm{~min}$ at room temperature. Optical density was read at $530 \mathrm{~nm}$ with a spectrophotometer (Spectronic 20; Spectronic Instruments, Rochester, NY). For most experiments, the volumes were modified such that the assay could be performed in 48 -well culture plates (BD Biosciences, Bedford, MA) and optical density was read with an optical plate reader (Elx 100; Bio-Tek Instruments, Inc., Winooski, VT). A range of concentrations (0.0 to $10.0 \mathrm{mg} / \mathrm{ml}$ ) of synthetic IAA was used as a standard. Each bacterial isolate was tested at least twice for production of IAA in vitro. Results were analyzed using KC Junior software (Bio-Tek Instruments, Inc.). The variability of the IAA assay was determined using the general linear model procedure of SAS statistical software (version 8, SAS Institute, Cary, NC).

IAA production during bacterial growth. The purpose of this experiment was to determine the bacterial growth stage and the number of cells of P. agglomerans 4/99 or E. herbicola 299R that were required before IAA could be detected in the culture medium. Bacteria were grown in LB broth as described previously, and three replicates were assayed at 4-h intervals for $48 \mathrm{~h}$. Cell numbers were estimated from serial dilutions on LB agar, and IAA was measured using Gordon and Weber's colorimetric assay (17) as described previously. The experiment was performed twice.

Relationship between IAA production and gall formation. To determine whether production of IAA by bacteria in vitro and the ability of bacteria to cause galls were related, the Spearman correlation coefficient was computed using the data from pathogenicity tests and IAA production assays. Data used for the analysis are reported in Table 2.

IAA production by bacteria from sites differing in stem gall history. Plant and soil samples were collected at two sites in central Wisconsin in 2002 and 2003. One site was sampled in both years, whereas the second site sampled was different in the 2 years. Two beds were chosen at each site: one in which stem gall had been observed in the past 2 years and one in which stem gall had never been observed. Sampling was done on 13 and 20 June and 11 September 2002; and 13 May and 30 June 2003. From each bed, five soil samples (top 2 to $3 \mathrm{~cm}$, including leaf debris and rhizosphere soil) and five plant samples (10 to 15 asymptomatic shoots) were collected and brought to the laboratory. One to three grams of soil or plant sample was sonicated $(50$ to $60 \mathrm{~Hz}, 2 \mathrm{Amp})$ for $7 \mathrm{~min}$ in $50 \mathrm{ml}$ of phosphate-buffered saline $(\mathrm{pH} 7.0)$ in a Cavitator Ultrasonic Cleaner 4.6 (Mettler Electronics Corp., Anaheim, CA). Following sonication, samples were agitated for $30 \mathrm{~s}$ (in 2002) or $15 \mathrm{~min}$ (in 2003), serial dilutions were plated onto KB (2002) or $10 \%$ tryptic soy agar (TSA, 2003) amended with cycloheximide (100 mg/liter). Plates were incubated at room temperature, and after 5 days, colonies were selected for further analysis. In 2002, bacterial colonies were selected based on morphological diversity (color, shape, and texture). The number of colonies of each morphological type chosen was in proportion to its occurrence on plates. In 2003, 30 colonies, regardless of morphology, were arbitrarily selected from each sample. A total of 400 and 2,000 bacterial colonies from soil and plant samples was assayed for IAA production in 2002 and 2003, respectively. A subset of isolates, including 18 isolates from 2002 and 38 isolates from 2003 that varied in IAA production, was identified by $16 \mathrm{~S}$ rRNA gene sequencing and tested for pathogenicity on cranberry.

Statistical analysis of IAA production among bacteria from sites with varying disease history was performed using the mixed model procedure of SAS (version 8.0, SAS Institute). The data were organized in a randomized design with subsampling in which stem gall history of the bed (positive or negative), type of sample (plant or soil), and time of sampling (earlier or later in the year) were tested as fixed effects.
TABLE 3. Characterization of bacteria isolated from plant and soil samples from cranberry beds differing in stem gall history

\begin{tabular}{|c|c|c|c|}
\hline Year & 16S rRNA gene sequence identity ${ }^{x}$ & Galls ${ }^{\mathrm{y}}$ & $\begin{array}{c}\text { IAA } \\
(\mu \mathrm{g} / \mathrm{ml})^{\mathrm{z}}\end{array}$ \\
\hline $\begin{array}{l}\text { Plant } \\
2002\end{array}$ & $\begin{array}{l}\text { ith past history of stem gall } \\
\text { Burkholderia sp. (98) } \\
\text { Curtobacterium sp. (99) } \\
\text { Microbacterium sp. (98) } \\
\text { Pseudomonas gingeri (98) } \\
\text { NT }\end{array}$ & $\begin{array}{l}\text { NT } \\
+ \\
+ \\
+ \\
+\end{array}$ & $\begin{array}{l}0.4 \\
2.0 \\
3.0 \\
5.3 \\
1.5\end{array}$ \\
\hline 2003 & $\begin{array}{l}\text { Agrobacterium rubi }(\text { partial) } \\
\text { Frigoribacterium sp. }(96) \\
\text { Pseudomonas alcaligenes }(98) \\
\text { Pseudomonas gingeri }(96) \\
\text { Pseudomonas gingeri }(98) \\
\text { Pseudomonas gingeri }(96) \\
\text { Pseudomonas gingeri }(98) \\
\text { Pseudomonas gingeri }(97) \\
\text { Pseudomonas rhodesiae }(99) \\
\text { Pseudomonas syringae } \\
\text { pv. glycinea }(98)\end{array}$ & $\begin{array}{c}- \\
- \\
\text { NT } \\
- \\
++ \\
+ \\
+ \\
++ \\
\text { NT }\end{array}$ & $\begin{array}{l}4.8 \\
0.0 \\
9.0 \\
4.2 \\
4.8 \\
5.7 \\
4.5 \\
6.1 \\
0.0\end{array}$ \\
\hline $\begin{array}{l}\text { Plant } \\
2002\end{array}$ & $\begin{array}{l}\text { ith no past history of stem gall } \\
\text { Pseudomonas corrugata (98) } \\
\text { Pseudomonas } \mathrm{sp} .(98) \\
\text { Rhodococcus } \mathrm{sp} .(99)\end{array}$ & $\begin{array}{l}+ \\
- \\
-\end{array}$ & $\begin{array}{l}4.7 \\
2.8 \\
0.3\end{array}$ \\
\hline 2003 & $\begin{array}{l}\text { Agromyces ramosum }(96) \\
\text { Burkholderia caryophylli }(96) \\
\text { Frigoribacterium sp. }(97) \\
\text { Pseudomonas gingeri }(98) \\
\text { Pseudomonas gingeri }(97) \\
\text { Pseudomonas gingeri }(96) \\
\text { Pseudomonas gingeri }(98) \\
\text { Rhizobium sp. (partial) } \\
\text { Staphylococcus sp. }(99) \\
\text { Staphylococcus } \text { sp. }(99)\end{array}$ & $\begin{array}{l}+ \\
- \\
+ \\
+ \\
+ \\
+ \\
+ \\
++ \\
+ \\
-\end{array}$ & $\begin{array}{l}4.8 \\
0.0 \\
0.0 \\
5.0 \\
6.3 \\
6.5 \\
4.3 \\
3.7 \\
0.0 \\
0.0\end{array}$ \\
\hline $\begin{array}{l}\text { Soil s } \\
2002\end{array}$ & $\begin{array}{l}\text { th past history of stem gall } \\
\text { Bacillus cereus }(99) \\
\text { Bacillus sp. (99) } \\
\text { Microbacterium foliorum (98) } \\
\text { Paracoccus } \text { sp. (99) } \\
\text { Rhizobium rhizogenes (99) }\end{array}$ & $\begin{array}{l}- \\
- \\
+ \\
- \\
-\end{array}$ & $\begin{array}{r}0.2 \\
0.0 \\
11.1 \\
0.1 \\
0.0\end{array}$ \\
\hline 2003 & $\begin{array}{l}\text { Agrobacterium rubi (99) } \\
\text { Bacillus cereus }(99) \\
\text { Burkholderia } \text { sp. }(99) \\
\text { Flavobacterium herparinum (97) } \\
\text { Flavobacterium indologenes }(94) \\
\text { Pseudomonas sp. }(98) \\
\text { Rahnella aquatilis, } \\
\text { Yersinia intermedia (96) } \\
\text { Rahnella aquatilis }(97) \\
\text { Rahnella sp. }(98) \\
\text { Variovorax sp. }(95) \\
\text { Yersinia intermedia }(97)\end{array}$ & $\begin{array}{l}++ \\
+ \\
- \\
- \\
++ \\
- \\
+ \\
+ \\
+ \\
\text { NT } \\
+\end{array}$ & $\begin{array}{l}2.1 \\
8.0 \\
0.0 \\
4.5 \\
5.6 \\
8.0 \\
\\
5.4 \\
5.0 \\
0.0 \\
0.0 \\
3.7\end{array}$ \\
\hline $\begin{array}{l}\text { Soil s } \\
2002\end{array}$ & $\begin{array}{l}\text { th no past history of stem gall } \\
\text { Arthrobacter } \mathrm{sp} .(99) \\
\text { Bacillus cereus (99) } \\
\text { Enterobacter nimipressuralis (99) } \\
\text { Gamma proteobacterium (98) } \\
\text { Pseudomonas } \mathrm{sp} .(99) \\
\text { Rhizobium } \text { sp. (98) }\end{array}$ & $\begin{array}{l}+ \\
- \\
++ \\
- \\
+ \\
+\end{array}$ & $\begin{array}{r}10.2 \\
0.0 \\
5.5 \\
0.0 \\
18.4 \\
2.1\end{array}$ \\
\hline 2003 & $\begin{array}{l}\text { Arthrobacter methylotrophus (97) } \\
\text { Bacillus cereus }(97) \\
\text { Chryseobacterium } \mathrm{sp} .(96) \\
\text { Mesorhizobium } \mathrm{sp} .(87) \\
\text { Staphylococcus } \mathrm{sp} .(99) \\
\text { Staphylococcus } \mathrm{sp} .(97) \\
\text { Pseudomonas } \mathrm{sp} \text {. (partial) (90) }\end{array}$ & $\begin{array}{l}+ \\
- \\
- \\
- \\
+ \\
- \\
-\end{array}$ & $\begin{array}{l}4.1 \\
0.0 \\
4.0 \\
0.0 \\
5.6 \\
0.0 \\
4.0\end{array}$ \\
\hline
\end{tabular}

${ }^{\mathrm{x}}$ Bacteria identified by $16 \mathrm{~S}$ rRNA gene sequencing; numbers in parentheses indicate percent sequence identity to taxa in the database. If two taxa are listed, there was a tie in percent sequence identity.

$\mathrm{y}_{-},+$, and ++ indicate galls formed on $0 \%, 10$ to $80 \%$, and $>80 \%$ of micropropageted plants, respectively. NT, not tested.

${ }^{\mathrm{z}}$ Indole-3-acetic acid (IAA) production measured using the colorimetric assay of Gordon and Weber (17). Data are averages from at least two assays for each isolate. 


\section{RESULTS}

Identification of bacteria isolated from cranberry galls. Forty-four bacterial isolates from galls were identified by $16 \mathrm{~S}$ rRNA gene sequencing (Table 2), based on at least $92 \%$ identity to bacterial sequences recorded in public databases. In most cases, identification was based on 97 to $99 \%$ sequence identity. Most bacteria from cranberry galls belonged to one of three taxonomic groups: (i) Enterobacteriaceae, including the genera Enterobacter, Pantoea, and Serratia; (ii) Agrobacterium/Rhizobium spp.; and (iii) Pseudomonas spp. Only two isolates from galls were identified as species outside these three main groups.

Pathogenicity tests. Inoculation of woody plants generally did not result in galls resembling field symptoms. In a few cases, a single, small gall developed, but we did not consistently produce galls with any bacterial strain using any of the four methods tested. All 11 Enterobacteriaceae strains that were isolated from cranberry caused galls on micropropagated cranberry plants, with
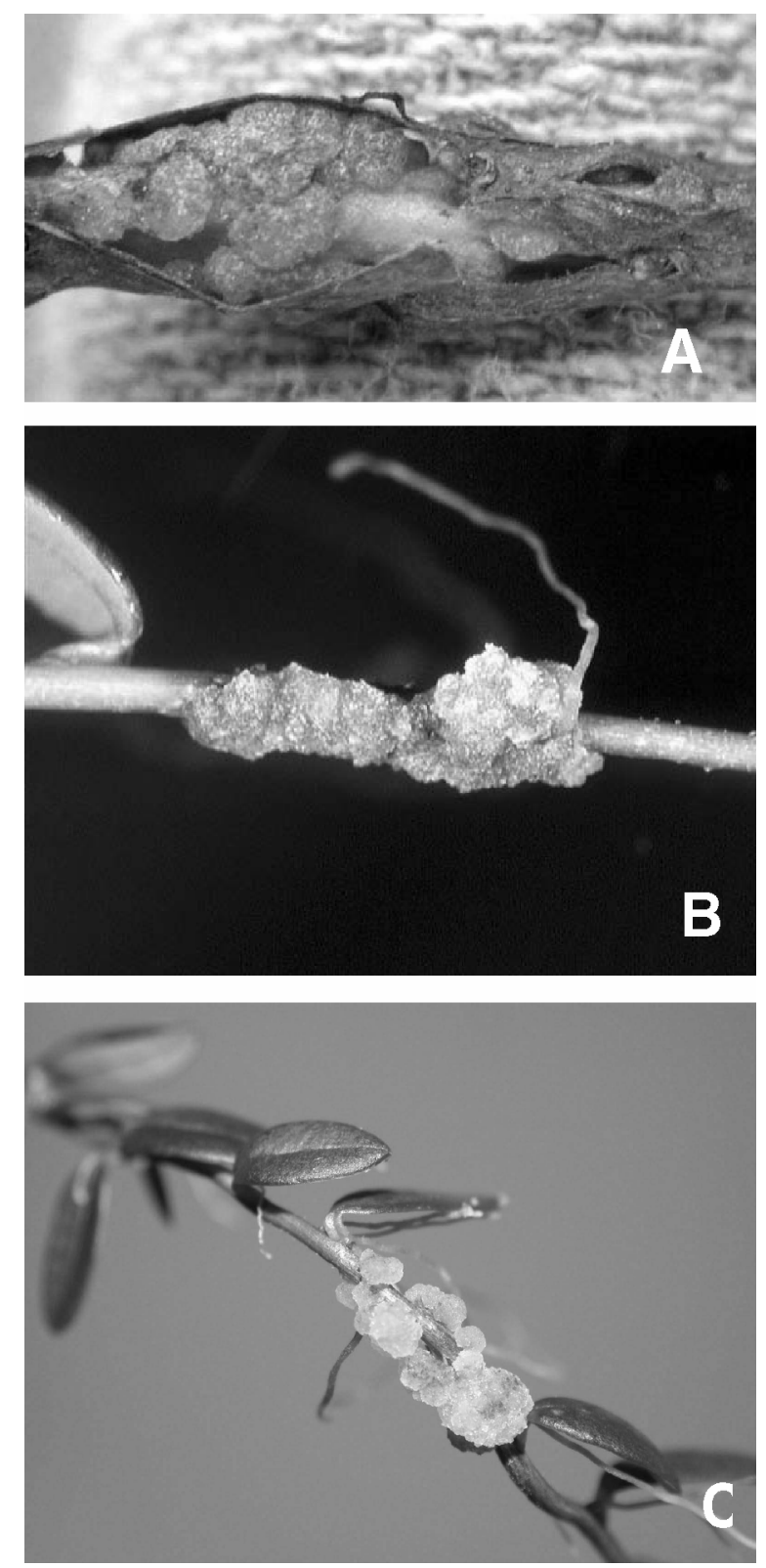

Fig. 1. A, Galls on a cranberry stem from the field, about seven times larger than actual size. B, Galls caused by Pantoea agglomerans 4/99 on a micropropagated cranberry stem, about five times larger than actual size. C, Galls caused by Agrobacterium tumefaciens 759 on a micropropagated cranberry stem, about four times larger than actual size. most strains causing galls on more than $80 \%$ of plants inoculated (Table 2). Twelve of the fifteen Agrobacterium/Rhizobium strains included in pathogenicity tests caused galls on 10 to $50 \%$ of plants inoculated (Table 2), but the galls were smaller than galls caused by strains in the family Enterobacteriaceae. Four of fifteen Pseudomonas strains caused galls that appeared similar to galls caused by members of the family Enterobacteriaceae (Table 2). Galls and tissue swelling caused by P. agglomerans 4/99 were spread over the region of wounding (Fig. 1). Galls caused by A. tumefaciens 759 (Fig. 1), A. tumefaciens C58, and A. rubi ATCC 13335 were bulbous and increased in size over time, whereas galls caused by strains of $P$. agglomerans and $E$. herbicola were usually smaller, more closely appressed to the stem, and did not increase in size after 4 weeks. Bacteria previously reported to produce IAA, including E. herbicola pv. betae, E. herbicola pv. gypsophilae, E. herbicola $112 \mathrm{Y}$, and E. herbicola 299R, caused galls on 73 to $100 \%$ of plants that were inoculated (Table 1). E. herbicola MX149 (E. herbicola 299R AipdC) caused galls that appeared similar to galls caused by other members of the family Enterobacteriaceae, but on a smaller proportion of plants compared with that of the parental wild-type strain, E. herbicola 299R. Galls formed by E. amylovora and E. stewartii were smaller than galls caused by strains of E. herbicola.

Dose-response studies. At least $10^{7} \mathrm{CFU}$ of $P$. agglomerans $4 / 99$ were needed for gall formation on at least $50 \%$ of the plants inoculated (Fig. 2). More than $10^{7} \mathrm{CFU}$ of both E. herbicola 299R and E. herbicola MX149 were required for symptom formation on micropropagated cranberry plants (data not shown).

Effect of synthetic IAA. The lowest concentration of synthetic IAA that visibly altered plant development was $0.5 \mathrm{mg} / \mathrm{ml}$. Stems were swollen and adventitious roots developed at the wound sites treated with IAA (data not shown). At a concentration of $10.0 \mathrm{mg} / \mathrm{ml}$, roots at the wound site were so numerous that they obscured the stem.

Bacterial production of IAA. IAA production by members of the family Enterobacteriaceae isolated from cranberry galls ranged from 2.6 to $14.9 \mu \mathrm{g} / \mathrm{ml}$ (Table 2). IAA production by members of the Agrobacterium/Rhizobium and Pseudomonas groups ranged from 0.0 to $2.9 \mu \mathrm{g} / \mathrm{ml}$ and 0.5 to $6.2 \mu \mathrm{g} / \mathrm{ml}$ (Table 2). The mean square error from the analysis of variance of the IAA production data was $4.5 \mu \mathrm{g} / \mathrm{ml}$. Measurement of IAA during growth of $P$. agglomerans 4/99 and E. herbicola 299R showed that both strains reached stationary phase (approximately $10^{9} \mathrm{CFU} / \mathrm{ml}$ ) before IAA was detected (Fig. 3).

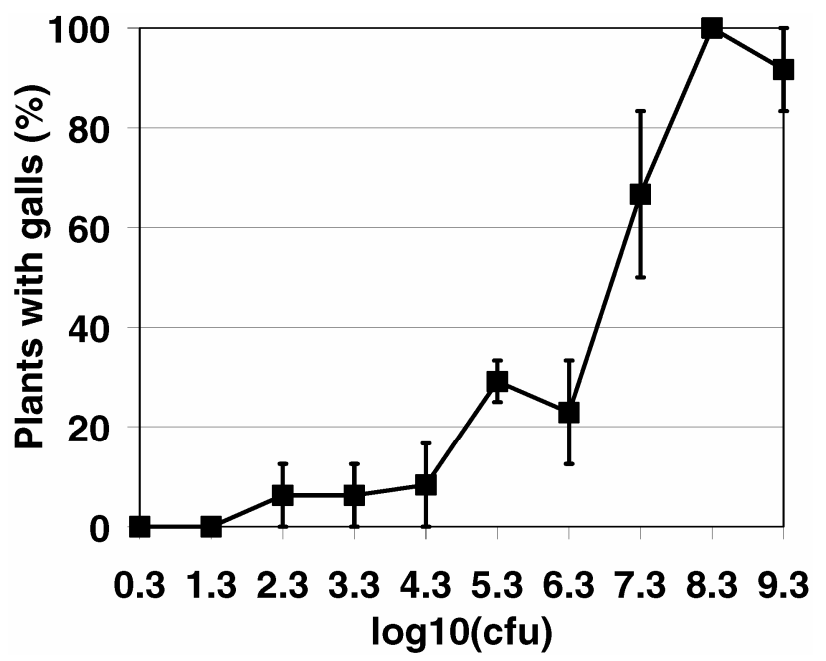

Fig. 2. Percentage of micropropagated cranberry plants that developed galls after inoculation with a range of colony forming units (CFU) of Pantoea agglomerans 4/99. Six to ten plants were used in each experiment. Results shown are the average of two experiments. Bars indicate one standard error greater than and less than the mean. 
Relationship between IAA production and gall formation. Nonparametric analysis indicated a highly significant correlation $(P=0.0004)$ between IAA production by bacteria in vitro and gall formation by bacteria on micropropagated cranberry plants (Fig. 4).

Bacteria isolated from sites differing in stem gall history. Total culturable bacterial counts ranged from $1 \times 10^{4}$ to $5 \times$ $10^{6} \mathrm{CFU} / \mathrm{g}$ of plant or soil. Bacteria within the subset identified by $16 \mathrm{~S}$ rRNA sequencing were taxonomically diverse (Table 3 ). Several strains, regardless of sample type (plant versus soil) or bed stem gall history (positive versus negative), caused galls on micropropagated cranberry plants (Table 3 ).

In 2002, mean IAA production by bacteria was similar regardless of stem gall history of the beds from which samples were taken $(P=0.2679)$; however, in 2003 , mean IAA production was greater for bacteria isolated from beds with a history of stem gall than from beds with no history of stem gall $(P=0.0444)$ (Table 4). In 2002, mean IAA production was greater for bacteria from soil than from plants $(P=0.0795)$; however, in 2003 , mean IAA production was greater for bacteria from plants than from soil
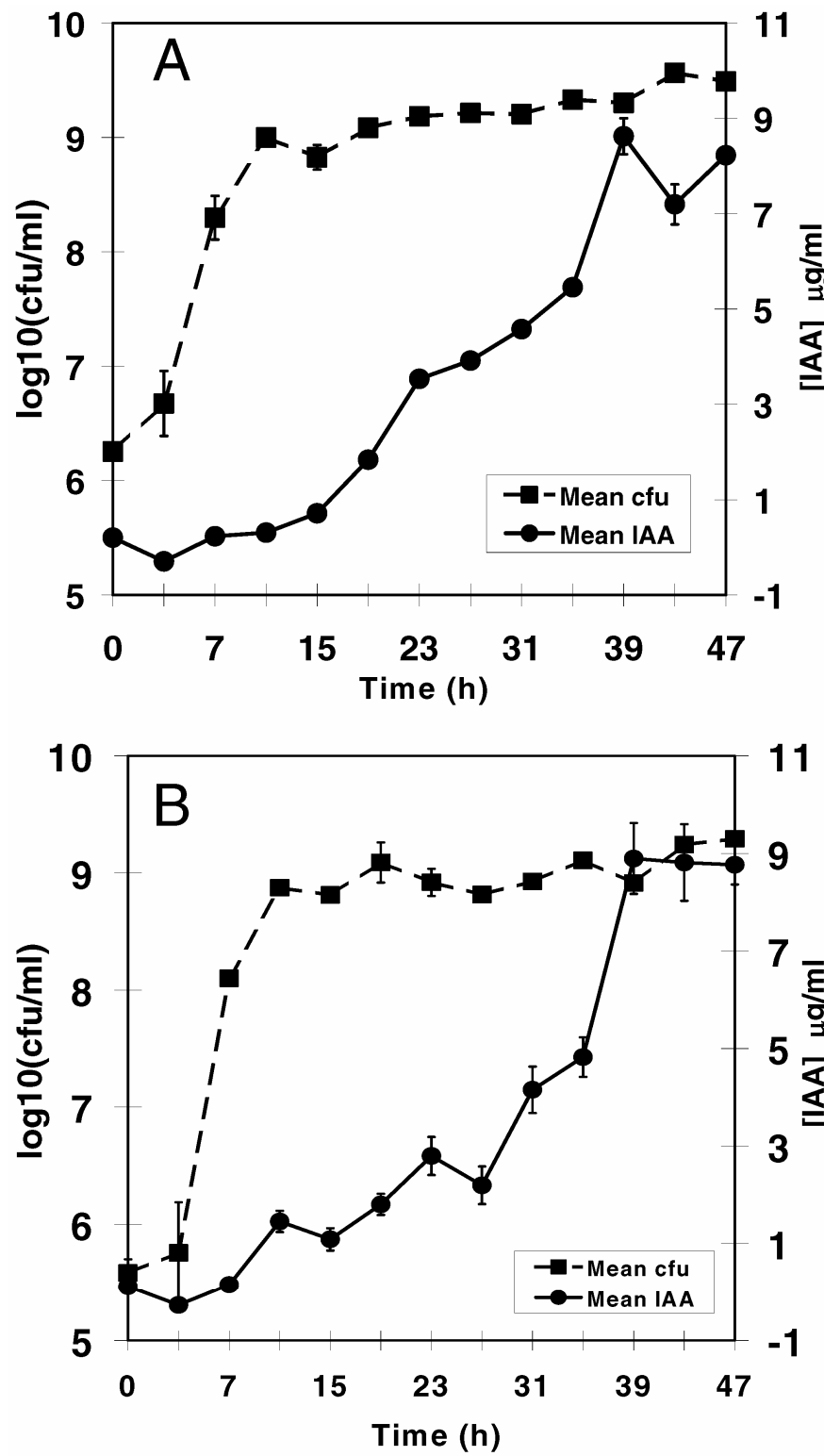

Fig. 3. Bacterial colony forming units (CFU) and indole-3-acetic acid (IAA) produced $(\mu \mathrm{g} / \mathrm{ml})$ by A, Pantoea agglomerans $4 / 99$ and B, Erwinia herbicola 299R. Data points are the average of three replicates at each time point. Bars indicate one standard error greater than and less than the mean. Data shown are from one experiment; similar results were obtained in a second experiment.
$(P=0.0574)$ (Table 4). In 2002, mean IAA production by bacteria was similar regardless of time of year that samples were taken $(P=0.6665)$; however, in 2003, mean IAA production was greater for bacteria isolated on 13 May than on 30 June $(P=$ 0.0017) (Table 4).

\section{DISCUSSION}

We identified and characterized bacteria isolated from cranberry stem galls. Among these, IAA-producing members of Enterobacteriaceae consistently caused galls on a large percentage of micropropagated cranberry plants. Several strains of Agrobacterium, Rhizobium, and Pseudomonas spp. also caused galls, although usually on a smaller percentage of plants inoculated. Galls caused by Agrobacterium spp. isolated from cranberry were relatively small, unlike the bulbous galls formed by A. tumefaciens 759 , which is known to carry the tumor-inducing plasmid. There was a positive correlation between IAA production by bacteria in vitro and gall formation. Bacteria that produced high levels of IAA generally caused galls on more than $80 \%$ of the plants inoculated. Treatment of cranberry stems with synthetic IAA also

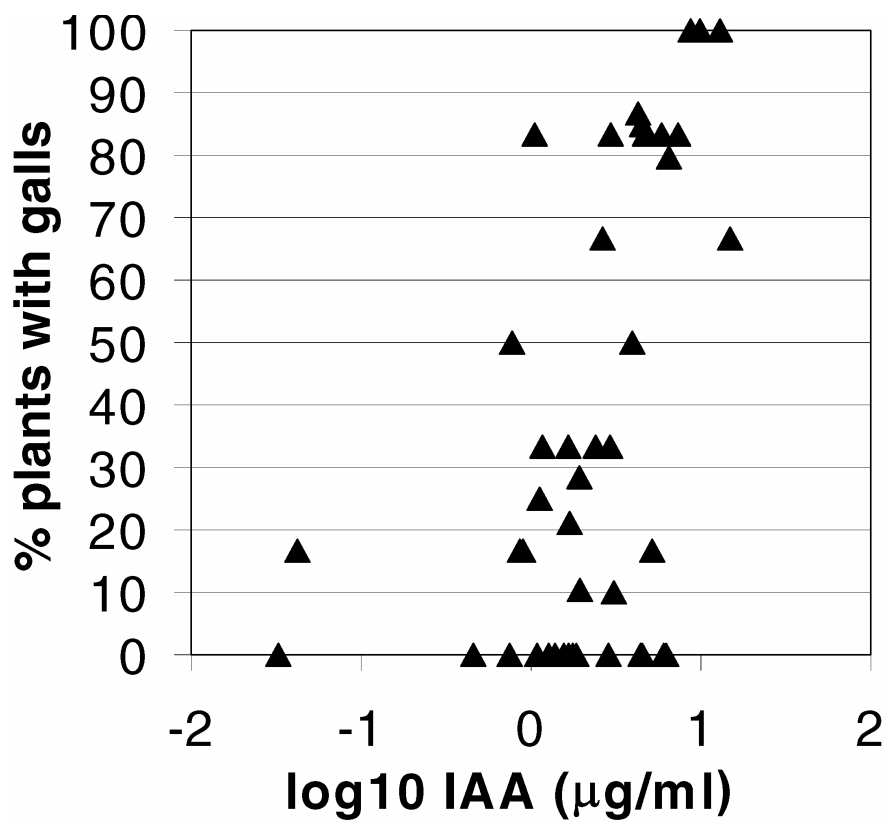

Fig. 4. Correlation of $\log _{10}$ concentration $(\mu \mathrm{g} / \mathrm{ml})$ of indole-3-acetic acid (IAA) produced by bacteria with percentage of micropropagated cranberry plants that developed galls when inoculated with bacteria.

TABLE 4. Significance of $F$ tests ( $P$ values) of analysis of variance of mean indole-3-acetic acid production among bacteria from cranberry beds with varying disease history

\begin{tabular}{lccc}
\hline & \multicolumn{3}{c}{ Factors tested as fixed effects $^{\mathrm{w}}$} \\
\cline { 2 - 4 } Year & $\begin{array}{c}\text { Stem gall history } \\
\text { (positive vs. negative) }^{\mathrm{x}}\end{array}$ & $\begin{array}{c}\text { Sample type } \\
\text { (plant vs. soil) }\end{array}$ & $\begin{array}{c}\text { Time of sampling } \\
\text { (earlier vs. later) }^{\mathrm{z}}\end{array}$ \\
\hline 2002 & 0.2679 & 0.0795 & 0.6665 \\
2003 & 0.0444 & 0.0574 & 0.0017 \\
\hline
\end{tabular}

${ }^{\mathrm{w}}$ Factors were tested as fixed effects in an analysis of variance using the mixed model procedure of SAS statistical software. A total of 400 and 2,000 bacterial isolates were assayed in 2002 and 2003, respectively.

${ }^{x}$ In each year, two beds were sampled at two sites: one with a history of stem gall (positive) and one without a history of stem gall (negative).

y Bacteria were isolated from five soil samples and five plant samples from each bed.

${ }^{\mathrm{z}}$ In 2002, samples were collected on 13 and 20 June (earlier) and 11 September (later). In 2003, samples were collected on 13 May (earlier) and 30 June (later). 
caused stem swelling, which except for excessive roots, appeared similar to symptoms induced by bacteria. The application of pure IAA to wounded plants instantaneously delivers the hormone. It is conceivable, however, that bacteria could deliver IAA at a slower rate over a longer period of time as their populations amass in plant tissues. If true, then application of IAA in a lanolin paste, which would slow the release of IAA, might produce symptoms even more similar to those induced by bacteria. In other recent work on stem gall, we report the localization of bacteria in galls and anatomical features of cranberry galls that are consistent with elevated levels of IAA (4). Taken together, these results support the hypothesis that IAA-producing bacteria cause cranberry stem gall and suggest that rather than one bacterial species being the cause, multiple strains of bacteria that produce IAA may be responsible for gall formation.

We did not create mutant strains of bacteria deficient in IAA production and then test their pathogenicity on cranberry. However, E. herbicola MX149, which carries a mutated indolepyruvate decarboxylase, an enzyme of a major IAA biosynthetic pathway, caused symptoms similar to those caused by the wild-type strain, E. herbicola 299R, albeit on a lower percentage of plants. Although this result initially was unexpected, it was consistent with our measurement of similar levels of IAA produced by the mutant and wild-type strain. The Gordon and Weber colorimetric assay used in this study was previously used to measure IAA production in bacteria isolated from pear orchards (22) and also provides a good estimate of IAA produced as measured by thin layer chromatography and high-performance liquid chromatography (HPLC) (24). However, in addition to IAA, the colorimetric assay detects indole-3-pyruvate (S. E. Lindow, personal communication), an intermediate that indolepyruvate decarboxylase converts to indole-3-acetaldehyde, which in turn is converted to IAA. Therefore, mutations in ipdC would result in the accumulation of indole-3-pyruvate and a positive result with the colorimetric assay. Previously, E. herbicola MX149 was shown to produce onetenth the IAA produced by the wild-type strain when measured by HPLC (6). This relatively low level of IAA may account for the galls that developed following inoculation with the mutant strain.

In dose-response studies, inoculation with at least $10^{7} \mathrm{CFU}$ of $P$. agglomerans $4 / 99$ was required for gall formation. In vitro, $P$. agglomerans $4 / 99$ reached stationary phase before IAA was detected. These findings suggest that after infection, bacteria must multiply to high populations before galls develop. In an accompanying report (4), we show that galls from the field contain cavities and fissures densely packed with bacteria, indicating that high numbers of bacteria do exist in galls under natural conditions.

As a first step toward understanding the ecology of IAA-producing bacteria associated with cranberry, we characterized bacteria isolated from plants and soil at sites that varied in stem gall history. In 2002, mean IAA production by bacteria was similar regardless of bed history, whereas in 2003, mean IAA production was significantly greater for bacteria isolated from beds with past occurrences of stem gall. However, our sampling and isolation protocols differed between years, which might have contributed to the inconsistent results across years. Factors that differed included (i) the sites sampled (one differed between years), (ii) the incubation periods following sonication (30 s in 2002 versus $15 \mathrm{~min}$ in 2003), (iii) the media used for isolation (KB in 2002 versus $10 \%$ TSA in 2003), (iv) the selection of isolates (based on morphological diversity in 2002 versus arbitrarily selected in 2003), and (v) the time at which samples were taken (June and September 2002 versus May and late June 2003). Our decision to sample in May 2003, which is about the time that plants are breaking dormancy, was based on anatomical evidence that IAA levels are high at the time that the vascular cambium resumes activity in the spring (4). Interestingly, there was a significant effect due to time of sampling in 2003, with greater IAA production from bacteria recovered on 11 May than on 30 June.
Despite several different methods of inoculation and attempts to simulate the natural environment of cranberry, we rarely produced galls on woody cranberry plants, and these symptoms did not closely resemble galls in the field (A. Vasanthakumar, unpublished data). The difficulty in reproducing symptoms and the sporadic occurrence of stem gall in the field despite the apparent ubiquity of IAA-producing bacteria suggest an especially critical role for environment in the development of symptoms. In other words, the bacteria that cause cranberry stem gall may be more dependent on abiotic cues and host status than are typical bacterial pathogens. Experimental evidence that the bacteria involved in stem gall are not classic pathogens includes the fact that $P$. agglomerans 4/99 did not incite a hypersensitive response on tobacco (A. Vasanthakumar, unpublished data) and apparently lacks hypersensitive response/pathogenicity ( $r r p$ ) genes that are conserved among gram-negative plant-pathogenic bacteria (31). Previous reports of epiphytic bacteria associated with pathological symptoms include E. herbicola and Pseudomonas spp. with pear russet (22) and ice-nucleating bacteria such as Pseudomonas syringae with frost injury (21). In the case of cranberry, IAA-producing bacteria might normally be beneficial by promoting adventitious root formation $(15,29)$, but then upon plant injury and as yet unknown environmental stimuli, symptom development ensues.

From an applied standpoint, identifying bacteria as the likely cause of cranberry stem gall is important for several reasons. Not knowing the cause of stem gall, some growers have attempted to treat the disease with synthetic fungicides. This expensive practice clearly is not justified based on the knowledge developed in the current study and other recent work on stem gall (4). Several formulations of copper hydroxide are registered for use on cranberry. While copper compounds are bactericidal, they generally are not effective in controlling plant diseases in which large populations of bacteria amass internally. The pattern of stem gall symptoms in the field often is indicative of infection through wounds caused by harvest machinery or exposure to fluctuating temperatures during winter. Therefore, avoidance of plant injury during harvest and protection with ice during winter are key recommendations for preventing cranberry stem gall.

\section{ACKNOWLEDGMENTS}

This research was supported by Hatch project WIS04448 through the College of Agricultural and Life Sciences, University of WisconsinMadison. We thank V. Best, S. Hemauer, and E. Pagel for technical help and insightful comments; E. Zeldin for advice on micropropagation of cranberry; several researchers cited in Table 1 for providing bacterial strains; and S. Lindow for insight on the IAA assay.

\section{LITERATURE CITED}

1. Altschul, S. F., Gish, W., Miller, W., Myers, E. W., and Lipman, D. J. 1990. Basic local alignment search tool. J. Mol. Biol. 215:403-410.

2. Barker, K. R., and Boone, D. M. 1966. Plant parasitic nematodes on cranberries in Wisconsin. Plant Dis. Rep. 50:957-959.

3. Bell, H. P. 1937. The origin of russeting in the golden russet apple. Can. J. Res. 15:560-566.

4. Best, V. M., Vasanthakumar, A., and McManus, P. S. 2004. Anatomy of cranberry stem gall and localization of bacteria in galls. Phytopathology 94:1172-1177.

5. Bird, G. W., and Jenkins, W. R. 1964. Occurrence, parasitism and pathogenicity of nematodes associated with cranberry. Phytopathology 54:677-680.

6. Brandl, M. T., and Lindow, S. E. 1996. Cloning and characterization of a locus encoding an indolepyruvate decarboxylase involved in indole-3acetic acid synthesis in Erwinia herbicola. Appl. Environ. Microbiol. 96:4121-4128.

7. Brandl, M. T., and Lindow, S. E. 1998. Contribution of indole-3-acetic acid production to the epiphytic fitness of Erwinia herbicola. Appl. Environ. Microbiol. 64:3256-3263.

8. Burr, T. J., Katz, B. H., Abawi, G. S., and Crosier, D. C. 1991. Comparison of tumorigenic strains of Erwinia herbicola isolated from table beet with E. h. gypsophilae. Plant Dis. 75:855-858. 
9. Caruso, F. L. 1992. A new upright dieback in 1992. Massachusetts Cranberry Experiment Station newsletter (August), East Wareham, MA.

10. Caruso, F. L. 1992. Stem canker update. Massachusetts Cranberry Experiment Station newsletter (November), East Wareham, MA.

11. Caruso, F. L., and Ramsdell, D. C. 1995. Compendium of Blueberry and Cranberry Diseases. The American Phytopathological Society, St. Paul, $\mathrm{MN}$.

12. Clark, E., Manulis, S., Ophir, Y., Barash, I., and Gafni, Y. 1993. Cloning and characterization of iaaM and iaaH from Erwinia herbicola pathovar gypsophilae. Phytopathology 83:234-240.

13. Costacurta, A., and Vanderleyden, J. 1995. Synthesis of phytohormones by plant-associated bacteria. Crit. Rev. Microbiol. 21:1-18.

14. El-Fiki, F., and Giles, K. L. 1981. Agrobacterium tumefaciens in agriculture and research. Pages 47-48 in: International Review of Cytology, Supplement 13: Biology of the Rhizobiaceae. K. L. Giles and A. G. Atherly, eds. Academic Press, New York.

15. Ercisli, S., Esitken, A., Cangi, R., and Sahin, F. 2003. Adventitious root formation of kiwifruit in relation to sampling date, IBA and Agrobacterium rubi inoculation. Plant Growth Reg. 41:133-137.

16. Gavini, F., Mergaert, J., Mielcarek, C., Izard, D., and Kersters, K. 1989. Transfer of Enterobacter agglomerans (Beijerinck 1888) Ewing and Fife 1972 to Pantoea gen. Nov. as Pantoea agglomerans comb. Nov. and description of Pantoea dispersa sp. Nov. Int. J. Syst. Bacteriol. 39:337-345.

17. Gordon, S. A., and Weber, R. P. 1951. Colorimetric estimation of indoleactic acid production. Plant Physiol. 26:192-195.

18. Kado, C. I., and Heskett, M. G. 1970. Selective media for isolation of Agrobacterium, Corynebacterium, Erwinia, Pseudomonas, and Xanthomonas. Phytopathology 60:969-976.

19. King, E. O., Ward, M. K., and Raney, D. E. 1954. Two simple media for the demonstration of pyocyanin and fluorescein. J. Lab. Clin. Med. 44:301-307.

20. Lane, D. J. 1991. 16S/23S rRNA sequencing. Pages 115-175 in: Nucleic Acid Techniques in Bacterial Systematics. Modern Microbiological Methods Series. E. Stackebrandt and M. Goodfellow, eds. John Wiley \& Sons, New York.
21. Lindow, S. E., Arny, D. C., and Upper, C. D. 1982. Bacterial ice nucleation: A factor in frost injury to plants. Plant Physiol. 70:1084-1089.

22. Lindow, S. E., Desurmont, C., Elkins, R., McGourty, G., Clark, E., and Brandl, M. T. 1998. Occurrence of indole-3-acetic acid-producing bacteria on pear trees and their association with fruit russet. Phytopathology 88:1149-1157.

23. Lloyd, G., and McCown, B. H. 1981. Commercially feasible micropropagation of mountain laurel (Kalmia latiflora) by use of shoot tip culture. Proc. Int. Plant Prop. Soc. 30:421-427.

24. Loper, J. E., and Schroth, M. N. 1986. Influence of bacterial sources of indole-3-acetic acid on root elongation of sugar beet. Phytopathology 76:386-389.

25. Manulis, S., Haviv-Chesner, A., Brandl, M. T., Lindow, S. E., and Barash I. 1998. Differential involvement of indole-3-acetic acid biosynthestic pathways in pathogenicity and epiphytic fitness of Erwinia herbicola pv. gypsophilae. Mol. Plant-Microbe Interact. 11:634-642.

26. Miller, T. D., and Schroth, M. N. 1972. Monitoring the ephiphytic population of Erwinia amylovora on pear with a selective medium. Phytopathology 62:1175-1182.

27. New, P. B., and Kerr, A. 1971. A selective medium for Agrobacterium radiobacter biotype 2. J. Appl. Bact. 34:223-233.

28. Patten, C. L., and Glick, B. R. 1996. Bacterial biosynthesis of indole-3acetic acid. Can. J. Microbiol. 42:207-220.

29. Patten, C. L., and Glick, B. R. 2002. Role of Pseudomonas putida indoleacetic acid in development of the host plant root system. Appl. Environ. Microbiol. 68:3795-3801.

30. Surico, G., Iacobellis, N. S., and Sisto, A. 1985. Studies on the role of indole-3-acetic acid and cytokinins in the formation of knots on olive and oleander plants by Pseudomonas syringae pv. savastanoi. Physiol. Plant Pathol. 26:309-320.

31. Vasanthakumar, A., Best, V. M., and McManus, P. S. 2002. Characterization of Pantoea agglomerans isolated from cranberry stem galls. (Abstr.) Phytopathology 92(suppl.):S83.

32. Vasanthakumar, A., and McManus, P. S. 2003. IAA-producing Pantoea agglomerans are associated with cranberry stem galls. (Abstr.) Phytopathology 93(suppl.):S87. 